\title{
13: 29938013-29931997
}

National Cancer Institute

\section{Source}

National Cancer Institute. 13: 29938013-29931997. NCI Thesaurus. Code C42472.

Physical location of HMGB1_Gene 